\title{
Normal nutrient ranges and nutritional monitoring of 'Pêra' orange trees based on the CND method in different fruiting stages
}

\author{
Jairo Rafael Machado Dias( ${ }^{(1)}$, Paulo Guilherme Salvador Wadt(2), Fábio Luiz Partelli(3), \\ Marcelo Curitiba Espindula(2), Daniel Vidal Perez ${ }^{(4)}$, Fábio Régis Souza(1), \\ Anderson Cristian Bergamin ${ }^{(1)}$ and Elaine Almeida Delarmelinda ${ }^{(1)}$
}

\begin{abstract}
(1)Universidade Federal de Rondônia, Departamento de Agronomia, Avenida Norte-Sul, no 7.300, Nova Morada, CEP 76940-000 Rolim de Moura, RO, Brazil. E-mail: jairorafaelmdias@unir.br, fabio.souza@unir.br, anderson.bergamin@unir.br, elainealmeida@unir.br (2)Embrapa Rondônia, BR-364, Km 5,5, Zona Rural, CEP 76815-800 Porto Velho, RO, Brazil.E-mail: wadt@dris.com.br, marcelo.espindula@embrapa.br (3)Universidade Federal do Espírito Santo, Rodovia BR 101 Norte, Km 60, Litorâneo, CEP 29932-540 São Mateus, ES, Brazil. E-mail: partelli@yahoo.com.br ${ }^{(4)}$ Embrapa Solos, Rua Jardim Botânico, no 1.024, Jardim Botânico, CEP 22460-000 Rio de Janeiro, RJ, Brazil. E-mail: daniel.perez@embrapa.br
\end{abstract}

\begin{abstract}
The objective of this work was to determine reference values for evaluating the nutritional status of 'Pêra' orange (Citrus sinensis) trees in different fruiting stages, using the compositional nutrient diagnosis (CND) method. The study used 243 leaf samples from 81 plots, with samplings performed in plants bearing fruits with three and six months of age, and also in the main harvest (nine months). Plots with productivity higher than $30 \mathrm{Mg} \mathrm{ha}^{-1}$ were selected for the establishment of reference standards. Three normal ranges were evaluated for each nutrient in the reference population, comprehended by the confidence interval (CI) of the foliar content averages, by the mean \pm standard deviation $( \pm \mathrm{SD})$, and by the mean $\pm 2 / 3 \mathrm{SD}$. Regardless of the normal range of nutrients used, the leaf sampling periods interfered with the nutritional status of 'Pêra' orange tree. The normal ranges obtained from the criteria $\mathrm{CI}$ and $\pm 2 / 3 \mathrm{SD}$ of the nutrient contents observed in the reference population frequently provided similar nutritional diagnoses. $\mathrm{Zn}, \mathrm{Ca}$, and $\mathrm{Fe}$ are the elements that most often limit the production of 'Pêra' orange in the state of Amazonas, Brazil.
\end{abstract}

Index terms: Citrus limonia, Citrus sinensis, DRIS, leaf sampling, nutritional balance index, reference population.

\section{Faixas normais de nutrientes e monitoramento nutricional de laranjeiras 'Pêra' com uso do método CND em diferentes estádios de frutificação}

\begin{abstract}
Resumo - O objetivo deste trabalho foi determinar valores de referência para avaliação do estado nutricional de laranjeiras 'Pêra' (Citrus sinensis) em diferentes estádios de frutificação, com uso do método de diagnose da composição nutricional (CND). Foram utilizadas 243 amostras foliares, provenientes de 81 glebas, com coletas em plantas com frutos de três e seis meses de idade e, também, na colheita principal (nove meses). Glebas com produtividade superior a $30 \mathrm{Mg} \mathrm{ha}^{-1}$ foram selecionadas para o estabelecimento dos padrões de referência. Foram avaliadas três faixas normais para cada nutriente, na população de referência, abrangidas entre o intervalo de confiança (IC) das médias dos teores foliares, a média \pm desvio-padrão $( \pm D P)$ e a média $\pm 2 / 3 D P$. Independentemente da faixa normal de nutrientes utilizada, a época de amostragem foliar interferiu no estado nutricional da laranjeira 'Pêra'. As faixas normais obtidas a partir dos critérios IC e $\pm 2 / 3 \mathrm{DP}$ dos teores nutricionais observados na população de referência proporcionaram diagnósticos nutricionais frequentemente semelhantes. Zn, $\mathrm{Ca}$ e Fe são os elementos que mais frequentemente limitam a produção da laranja 'Pêra' no Amazonas.
\end{abstract}

Termos para indexação: Citrus limonia, Citrus sinensis, DRIS, amostragem foliar, índice de balanço nutricional, população de referência.

\section{Introduction}

The citrus sector of Brazil contributes substantially to the economy of the country and is the largest exporter of concentrated orange juice in the world (Perez \& Santos, 2014). The state of São Paulo is the greatest orange producer in the country, with a harvested area of 46,043 ha, while the state of Amazonas ranks $11^{\text {th }}$, with a harvested area of 2,651 ha (IBGE, 2014).

In Amazonas, orange production is concentrated in the municipality of Rio Preto da Eva, which accounts for more than $70 \%$ of the state production. The orange variety 'Pêra' [Citrus sinensis (L.) Osbeck] is the most commonly cultivated, due to its easy adaptation to

Pesq. agropec. bras., Brasília, v.52, n.9, p.776-785, set. 2017

DOI: 10.1590/S0100-204X2017000900010 
the regional soil-climatic conditions (IBGE, 2014). However, information on the nutritional status of fruit trees in the region is scarce, and nutritional standards established in other states are still commonly used (Fernandes et al., 2010). However, this procedure can affect the efficiency of nutritional assessment due to variations, mainly, in non-nutritional factors (Jarrel \& Beverly, 1981).

The sufficiency range (SR) and critical level (CL) are the most widely used methods for interpretation of leaf analysis. These reference values are traditionally obtained in calibration tests in which the nutrient rates are varied and all the other production factors are maintained constant (Kurihara et al., 2005). However, the long time and high costs required to establish the standard values are the main drawbacks of these methods, besides the limitations arising from the requirement that the cultivation conditions of the plants to be diagnosed must be similar to those of the plants used to obtain the calibration curve (Fageria et al., 2009).

Alternatively, the use of SR derived from the diagnosis and recommendation integrated system (DRIS) applied directly to commercial plantations has been proposed in the literature, requiring no experimentation, with a significant reduction in cost and time demand necessary to establish the standards. This possibility has stimulated more and more research on fruit trees such as: banana tree (Teixeira et al., 2007), coconut tree (Santos et al., 2004), guava tree (Souza et al., 2013), mango tree (Politi et al., 2013), and mandarin (Srivastava \& Singh, 2008). For orange trees, SRs have been proposed for the state of São Paulo (Camacho et al., 2012) and Central Amazon (Dias et al., 2013).

The application of orange tree fertilization in Brazil is best done at the beginning of fruiting (Mourão Filho, 2005; Santana et al., 2007; Fernandes et al., 2010). However, the crop leaf sampling period proposed in the literature prevents the nutritional diagnosis from being timely made for use in fertilization recommendation in the same year, since leaf sampling is only recommended when the fruits are six months old (Quaggio et al., 2005). This limitation has made nutritional diagnosis little widespread as a tool for the management of orange tree fertilization (Mourão Filho, 2005; Camacho et al., 2012; Dias et al., 2013).

The DRIS method varies according to the nutritional relationships used, which can be bi- or multivariate.
As an approach to a distinct diagnostic system, Parent \& Dafir (1992) proposed DRIS based on multivariate relationships, called compositional nutrient diagnosis (CND). The CND corresponds to the natural logarithm of the relationship between the evaluated nutrient and the geometric mean of the nutritional composition in the leaf sample (Parent, 2011). Therefore, unlike the original DRIS method (Beaufils, 1973), CND does not consider the relationship between the contents of two discretionary nutrients.

The establishment of normal nutrient ranges for different fruiting stages of orange tree is essential so that the foliar analysis can be used as a decision tool in the management of the crop's main fertilization.

The objective of this work was to determine reference values for evaluating the nutritional status of 'Pêra' orange trees in different fruiting stages, using the compositional nutrient diagnosis (CND) method.

\section{Materials and Methods}

The study was carried out in the municipality of Rio Preto da Eva $\left(02^{\circ} 41^{\prime} 56^{\prime \prime} \mathrm{S}, 59^{\circ} 42^{\prime} 00^{\prime \prime} \mathrm{W}\right)$, in the state of Amazonas, Brazil, using 243 leaf samples of 'Pêra' orange tree [Citrus sinensis (L.) Osbeck]. The trees were grafted on 'Cravo' lemon (Citrus limonia Osbeck) tree and sampled in the 2011/2012 growing season, in three fruiting stages. The samples were collected from 27 representative commercial orchards of this orangeproducing region.

Each orchard was divided into three plots, representing the different micro soil-climatic conditions within the orchard, in order to maintain visual uniformity within the areas, with four orange trees per plot, to ensure representativeness. Therefore, 81 plots were monitored. The evaluated orchards were between 5 and 15 years old, producing yields between 10.9 and $55.8 \mathrm{Mg} \mathrm{ha}^{-1}$. The orchards were planted at a spacing of $7 \times 4 \mathrm{~m}$, with a total of 357 plants per hectare, and at $8.5 \times 5 \mathrm{~m}$, with 236 plants per hectare. The evaluated orchards were cultivated in a dry system, and the main harvest occurred in June, while untimely fruits were harvested in September and October.

The climate of the region is Af type, according to Köppen's classification, with tropical humid conditions and annual means of $26^{\circ} \mathrm{C}$ and $2,550-\mathrm{mm}$ precipitation. The rainy season lasts from December to April, with 
rainfalls concentrated in the first quarter of the year, and the warmest period lasts from August to October. Latossolos Amarelos distróficos (Xanthic Oxisols) are predominant in the region (IBGE, 2010).

Sampling periods for nutritional diagnosis were selected to identify the ideal fruiting stage to evaluate possible nutritional imbalances. In the first period, leaf sampling was carried out when the plants showed threemonth-old fruits (marble-sized fruit, corresponding to stage 6), in December 2011. In the second period, sampling was performed in March 2012, when the fruits were six months old (final size fruit, green, stage 8), according to Quaggio et al. (2005). In the third sampling period, the leaves were taken at the time of the main harvest (green to yellow fruit, stage 9), in June 2012. Each sample was composed of 100 freshly ripened leaves taken from four trees ( 25 leaves per plant), selected at random within the field. The leaves were removed from the third node from the apex of fruiting branches.

The collection was rigorously standardized, since the leaf patterns differ according to the type of the leaf samples (Kurihara et al., 2013). The samplings were performed on the sides of the trees facing the four cardinal points, and always at medium plant height, as recommended by Quaggio et al. (2005). The collected plant material was packed in paper bags and transported to the laboratory. For the analyses, the samples were washed in running water, dried in a forced air circulation oven at $60^{\circ} \mathrm{C}$, ground in a Willey mill, and the total nutrient contents were determined.

To analyze the $\mathrm{P}, \mathrm{K}, \mathrm{Ca}, \mathrm{Mg}, \mathrm{B}, \mathrm{Cu}, \mathrm{Fe}, \mathrm{Mn}$, and $\mathrm{Zn}$ contents, the samples were solubilized in nitric-perchloric solution (65\% nitric acid and 70\% perchloric acid), while nitrogen was subjected to sulfuric solubilization and determined by the semimicro Kjeldahl method (Carmo et al., 2000).

In 51 of the 81 plots monitored, the fruit yields exceeded $30 \mathrm{Mg} \mathrm{ha}^{-1}$ in the main harvest (June 2012). These 51 plots were considered as the reference population to determine the nutritional standards. The other 30 plots had low yields and were used to perform the nutritional diagnoses. The yield of $30 \mathrm{Mg} \mathrm{ha}^{-1}$ was used as a cutoff criterion for being more than $50 \%$ higher than the mean yield of orange trees in the state of Amazonas, in 2012 (IBGE, 2014).

In the plots of the reference population, the following mean values were found in the soil chemical analyses (0.0-0.20 m layer): $\mathrm{pH}$ in $\mathrm{CaCl}_{2}$ 5.7; $\mathrm{P}$ (Mehlich-1) $5.6 \mathrm{mg} \mathrm{dm}{ }^{-3} ; \mathrm{Ca}, \mathrm{Mg}, \mathrm{K}$, and potential acidity of 2.3 , $1.2,0.2$, and $2.9 \mathrm{cmolc} \mathrm{dm}^{-3}$, respectively; oxidizable organic carbon of $3.0 \mathrm{dag}^{\mathrm{kg}^{-1}}$; and clay content of $59.3 \mathrm{dag} \mathrm{kg}^{-1}$. In the low-yield plots $\left(\leq 30 \mathrm{Mg} \mathrm{ha}^{-1}\right)$, the results of the soil analysis were: $\mathrm{pH}$ in $\mathrm{CaCl}_{2}$ of 5.4; $\mathrm{P}$ of $1.2 \mathrm{mg} \mathrm{dm}^{-3} ; \mathrm{Ca}, \mathrm{Mg}, \mathrm{K}$, and potential acidity of 1.7 ,

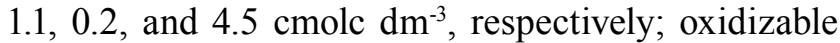
organic carbon of $3.2 \mathrm{dag} \mathrm{kg}^{-1}$; and clay content of 492 $\mathrm{g} \mathrm{kg}^{-1}$. The analyses were performed as proposed by Donagema et al. (2011).

Once the reference population was defined, the CND method (Parent, 2011) was used to identify the leaf nutrient concentrations in the samples that were sufficiently high, for each fruiting stage. To this end, the leaf concentration of nutrients in all plots, regardless of the sampling time, was adjusted to a same measure unit (dag $\left.\mathrm{kg}^{-1}\right)$.

Table 1. Mean and standard deviation from the nutritional standards used for the compositional nutrient diagnosis of 'Pêra' orange (Citrus sinensis) trees in different fruiting stages.

\begin{tabular}{|c|c|c|c|c|c|c|c|c|c|c|c|}
\hline Norm & $\mathrm{zN}$ & $\mathrm{zP}$ & $\mathrm{zK}$ & $\mathrm{zCa}$ & $\mathrm{zMg}$ & $\mathrm{zB}$ & $\mathrm{zCu}$ & $\mathrm{zFe}$ & $\mathrm{zMn}$ & $\mathrm{zZn}$ & zMS \\
\hline & \multicolumn{11}{|c|}{ 3-month-old fruits } \\
\hline Mean & 3.47 & 0.44 & 2.51 & 3.22 & 1.42 & -2.64 & -4.67 & -2.58 & -4.31 & -3.95 & 7.09 \\
\hline \multirow[t]{2}{*}{ Standard deviation } & 0.20 & 0.22 & 0.31 & 0.34 & 0.43 & 0.23 & 1.07 & 0.26 & 0.53 & 0.46 & 0.18 \\
\hline & \multicolumn{11}{|c|}{ 6-month-old fruits } \\
\hline Mean & 3.44 & 0.44 & 2.10 & 3.27 & 1.36 & -2.55 & -4.64 & -2.53 & -4.09 & -3.83 & 7.04 \\
\hline \multirow[t]{2}{*}{ Standard deviation } & 0.21 & 0.24 & 0.28 & 0.31 & 0.43 & 0.23 & 1.00 & 0.21 & 0.34 & 0.44 & 0.24 \\
\hline & \multicolumn{11}{|c|}{ Main harvest } \\
\hline Mean & 3.32 & 0.53 & 2.31 & 3.38 & 1.38 & -2.47 & -4.83 & -2.52 & -4.19 & -3.98 & 7.07 \\
\hline Standard deviation & 0.21 & 0.19 & 0.24 & 0.25 & 0.30 & 0.28 & 0.66 & 0.27 & 0.36 & 0.33 & 0.19 \\
\hline
\end{tabular}


The supplementary nutrient value for the total leaf biomass ( $\mathrm{R}$ value) was calculated according to the expression: $\mathrm{R}=100-(\mathrm{vN}+\mathrm{vP}+\mathrm{vK}+\mathrm{vCa}$ $+\mathrm{vMg}+\mathrm{vB}+\mathrm{vCu}+\mathrm{vFe}+\mathrm{vMn}+\mathrm{vZn})$, in which $\mathrm{R}$ is the complementary value for 100 dag $^{-1} \mathrm{~kg}^{-1}$ dry matter, in relation to the sum of nutrient contents vi $(\mathrm{i}=\mathrm{N}, \ldots, \mathrm{Zn})$, in dag $\mathrm{kg}^{-1}$. From the geometric mean (mGeo) calculated for the values of each sample, the multinutrient variable $(\mathrm{zX})$ was computed by the expression: $\mathrm{zX}=\ln (\mathrm{vX} / \mathrm{mGeo})$, where $\mathrm{zX}$ represents the value of the multivariate relation of each one of the evaluated nutrients (vX). With the $\mathrm{zX}$ values of each reference plot, the descriptive parameters - arithmetic mean $(\mathrm{mX})$ and standard deviation $(\mathrm{sX})$ - and the CND standards were calculated for each fruiting stage (Table 1).

From the standards, the CND indices were calculated by the log-centered multivariate correlation (Parent, 2011), for each of the evaluated nutrients: I_X $=(\mathrm{zX}-\mathrm{mX}) / \mathrm{sX}$; in which I_X represents the CND index; $\mathrm{mX}$ is the mean norm; and $\mathrm{sX}$ is the standard deviation norm.

For the interpretation of the CND indices, the DRIS dry matter method (M-DRIS) was used (Hallmark et al., 1987), and each nutrient was classified into two categories - deficiency and sufficiency - based on the comparison of the value of the CND index of each nutrient (In) with the CND dry matter index (DMI), where deficiency occurs when In $<0$ and In $<$ DMI; and sufficiency when In $>0$ or In $>$ DMI.

The normal range for each nutrient, irrespective of the fruiting stage, was estimated from the mean nutritional contents in the monitored plots with nutritional sufficiency, for each element analyzed, according to the thresholds: limits of the confidence interval (CI); of the standard deviation $( \pm \mathrm{SD})$; and of $\pm 2 / 3 \mathrm{SD}$. The CI was computed as: $\mathrm{CI}=\mathrm{mX} \pm \mathrm{t} \alpha \cdot \mathrm{s}_{\mathrm{mx}}$; where: $\mathrm{mX}$ and $\mathrm{s}_{\mathrm{mX}}$ represent the mean content and standard deviation for the nutrients evaluated in the nutritionally balanced plots, and t $\alpha$ is the value of bilateral $\mathrm{t}$, at $1 \%$ probability, with $\mathrm{n}-1$ degrees of freedom, where $\mathrm{n}$ refers to the total number of data.

The SD was obtained by the expression: $\mathrm{SD}=\left[\sum(\mathrm{yX}-\mathrm{mX})^{2}\right]^{0.5} / \mathrm{n}$; where: $\mathrm{y}$ and $\mathrm{m}$ represent the content of each sample and mean value, respectively; and $\mathrm{n}$, the total number of samples.

The amplitude of the CI, SD and $2 / 3 \mathrm{SD}$, expressed in grams per kilogram $\left(\mathrm{g} \mathrm{kg}^{-1}\right)$ for macronutrients, and in milligrams per kilogram ( $\left.\mathrm{mg} \mathrm{kg}^{-1}\right)$ for micronutrients, were considered as the normal range. Values below and above the lower and upper limits of $\mathrm{CI}, \mathrm{SD}$ and $2 / 3 \mathrm{SD}$ were considered as deficient and excessive nutritional contents (luxury consumption or toxicity), respectively.

In the low-yield plots, the nutritional diagnoses, carried out in the three fruiting stages, were compared with each other, and the concordance cases were computed for each leaf and nutrient sample. Therefore, concordant diagnoses were the cases in which the normal ranges - obtained with the different criteria at each fruiting stage - provided the same nutritional diagnosis of the samples (deficiency, balance and excess). The obtained results were expressed in percentage of agreement.

The norms, the CND indices, the M-DRIS, and the chi-square test $(p \leq 0.01)$ were calculated in a spreadsheet. The descriptive statistics and Tukey's test, at $5 \%$ probability, were processed with the statistical software Assistat, version 6.2 (Silva \& Azevedo, 2002).

\section{Results and Discussion}

Of the 81 commercial 'Pêra' orange plots monitored in the different fruiting stages, nutritional sufficiency was confirmed in the plots 45, 41, 50, 38, 49, 38, 38, 43, 40, and 32 for $\mathrm{N}, \mathrm{P}, \mathrm{K}, \mathrm{Ca}, \mathrm{Mg}, \mathrm{B}, \mathrm{Cu}, \mathrm{Fe}, \mathrm{Mn}$ and $\mathrm{Zn}$, respectively, in evaluations when the trees had three-month-old fruits. Similar results were found for the plots $60,44,59,35,50,34,33,38,31$, and 27 , when the fruits were six months old, and for the plots 51, 45, $53,36,58,42,37,41,33$, and 28 in the main harvest. Regardless of the fruiting stage evaluated, the N, P, $\mathrm{K}$, and $\mathrm{Mg}$ contents were found to have an adequate nutritional sufficiency in most of the monitored plots. However, in more than $60 \%$ of the plots, $\mathrm{Zn}$ was the most yield-limiting element (Table 2).

The distributions of the frequencies at which the plots were classified as nutrient-deficient and sufficient were similar for all nutrients, regardless of the fruiting stage (Table 2). This similarity in distribution can be explained by the low variations in the nutritional status between plots during fruiting.

From the CND results, the normal nutrient concentration was estimated based on the assumption that plants with higher nutritional CND indices than dry matter CND index were not affected by any yieldlimiting nutritional restriction (Hallmark et al., 1987). 
Table 2. Frequency at which a state of nutritional sufficiency and insufficiency was diagnosed in the 81 commercial 'Pêra' orange (Citrus sinensis) orchards, in the fruiting stages, evaluated by the method of compositional nutrient diagnosis ${ }^{(1)}$.

\begin{tabular}{|c|c|c|c|c|}
\hline Class & $\begin{array}{l}\text { 3-month- } \\
\text { old fruits }\end{array}$ & $\begin{array}{l}\text { 6-month- } \\
\text { old fruits }\end{array}$ & $\begin{array}{c}\text { Main } \\
\text { harvest }\end{array}$ & $\begin{array}{l}\text { Expected fre- } \\
\text { quency (\%) }\end{array}$ \\
\hline & \multicolumn{4}{|c|}{ Nitrogen } \\
\hline Sufficient & 56 & 74 & 63 & 64 \\
\hline Insufficient & 44 & 26 & 37 & 36 \\
\hline \multirow[t]{2}{*}{ Chi-square } & 3.25 & 4.24 & 0.07 & - \\
\hline & \multicolumn{4}{|c|}{ Phosphorus } \\
\hline Sufficient & 51 & 54 & 56 & 53 \\
\hline Insufficient & 49 & 46 & 44 & 47 \\
\hline \multirow[t]{2}{*}{ Chi-square } & 0.33 & 0.03 & 0.17 & - \\
\hline & \multicolumn{4}{|c|}{ Potassium } \\
\hline Sufficient & 62 & 73 & 65 & 67 \\
\hline Insufficient & 38 & 27 & 35 & 33 \\
\hline \multirow[t]{2}{*}{ Chi-square } & 1.10 & 1.71 & 0.07 & - \\
\hline & \multicolumn{4}{|c|}{ Calcium } \\
\hline Sufficient & 47 & 43 & 44 & 45 \\
\hline Insufficient & 53 & 57 & 56 & 55 \\
\hline \multirow[t]{2}{*}{ Chi-square } & 0.17 & 0.11 & 0.01 & - \\
\hline & \multicolumn{4}{|c|}{ Magnesium } \\
\hline Sufficient & 60 & 62 & 72 & 65 \\
\hline Insufficient & 40 & 38 & 28 & 35 \\
\hline \multirow[t]{2}{*}{ Chi-square } & 0.74 & 0.36 & 2.14 & - \\
\hline & \multicolumn{4}{|c|}{ Boron } \\
\hline Sufficient & 47 & 42 & 52 & 47 \\
\hline Insufficient & 53 & 58 & 48 & 53 \\
\hline \multirow[t]{2}{*}{ Chi-square } & 0.00 & 0.98 & 0.98 & - \\
\hline & \multicolumn{4}{|c|}{ Copper } \\
\hline Sufficient & 47 & 41 & 46 & 44 \\
\hline Insufficient & 53 & 59 & 54 & 56 \\
\hline \multirow[t]{2}{*}{ Chi-square } & 0.25 & 0.56 & 0.06 & - \\
\hline & \multicolumn{4}{|c|}{ Iron } \\
\hline Sufficient & 53 & 47 & 51 & 50 \\
\hline Insufficient & 47 & 53 & 49 & 50 \\
\hline \multirow[t]{2}{*}{ Chi-square } & 0.33 & 0.43 & 0.01 & - \\
\hline & \multicolumn{4}{|c|}{ Manganese } \\
\hline Sufficient & 49 & 38 & 41 & 43 \\
\hline Insufficient & 51 & 62 & 59 & 57 \\
\hline \multirow[t]{2}{*}{ Chi-square } & 1.77 & 0.84 & 0.17 & - \\
\hline & \multicolumn{4}{|c|}{ Zinc } \\
\hline Sufficient & 39 & 33 & 35 & 36 \\
\hline Insufficient & 61 & 67 & 65 & 64 \\
\hline Chi-square & 0.60 & 0.27 & 0.07 & - \\
\hline
\end{tabular}

(1)None of the chi-square values was considered significant at $5 \%$ probability.
Thus, the nutritional content in leaf tissues of the plots with sufficiency for each of the nutrients was used to establish the optimum concentration in the different fruiting stages of 'Pêra' orange tree.

In the 81 plots, the mean levels of $\mathrm{P}, \mathrm{Mg}, \mathrm{B}, \mathrm{Fe}$, and $\mathrm{Zn}$ were considered adequate; those of $\mathrm{K}, \mathrm{Ca}$ and $\mathrm{Mn}$ were low; and those of $\mathrm{N}$ and $\mathrm{Cu}$ were excessive for orange trees with 6-month-old fruits (Quaggio et al., 2005) (Table 3). However, in contrast to the normal nutrient range proposed by Camacho et al. (2012), with the use of CND in 'Pêra' orange trees cultivated in municipality of Bebedouro, state of São Paulo, Brazil, the mean $\mathrm{K}$ and $\mathrm{Fe}$ levels were considered adequate; those of $\mathrm{Ca}, \mathrm{Mg}$ and $\mathrm{Mn}$ were low; and those of $\mathrm{N}$, $\mathrm{P}, \mathrm{B}, \mathrm{Cu}$, and $\mathrm{Zn}$ were excessive, also for plants with 6-month-old fruits.

For the elements evaluated in the stage of fruit establishment (after three months), the leaf concentrations of $\mathrm{N}, \mathrm{K}$ and $\mathrm{Cu}$ were higher than those after six months, while those of $\mathrm{Mg}$ and $\mathrm{Zn}$ remained stable, and those of $\mathrm{P}, \mathrm{Ca}, \mathrm{B}, \mathrm{Fe}$, and $\mathrm{Mn}$ were lower. In 'Hamlin' orange trees, Mattos Junior et al. (2003) also observed a decrease in the $\mathrm{N}$ and $\mathrm{K}$ leaf concentrations as the fruiting satages advanced. These results can be explained by the fact that $\mathrm{N}$ and $\mathrm{K}$ are, in this order, the elements removed at highest levels in orange fruits (Boaretto et al., 2007). Thus, since the reproductive organs are preferential drains, these elements tend to

Table 3. Leaf contents in 'Pêra' orange (Citrus sinensis) trees in orchards with nutrient sufficiency (reference population), in samples taken at different fruiting stages ${ }^{(1)}$.

\begin{tabular}{|c|c|c|c|c|}
\hline \multirow[t]{2}{*}{ Nutrients } & \multicolumn{3}{|c|}{ Sampling time } & \multirow{2}{*}{$\begin{array}{c}\text { Coefficient } \\
\text { of variation } \\
(\%)\end{array}$} \\
\hline & $\begin{array}{l}\text { 3-month- } \\
\text { old fruits }\end{array}$ & $\begin{array}{l}\text { 6-month- } \\
\text { old fruits }\end{array}$ & $\begin{array}{c}\text { Main } \\
\text { harvest }\end{array}$ & \\
\hline $\mathrm{N}\left(\mathrm{g} \mathrm{kg}^{-1}\right)$ & $31.27 \mathrm{a}$ & $28.46 b$ & $27.66 \mathrm{~b}$ & 10.3 \\
\hline $\mathrm{P}\left(\mathrm{g} \mathrm{kg}^{-1}\right)$ & $1.35 \mathrm{~b}$ & $1.38 \mathrm{~b}$ & $1.47 \mathrm{a}$ & 7.7 \\
\hline $\mathrm{K}\left(\mathrm{g} \mathrm{kg}^{-1}\right)$ & $12.53 \mathrm{a}$ & $8.48 \mathrm{c}$ & $10.13 b$ & 18.5 \\
\hline $\mathrm{Ca}\left(\mathrm{g} \mathrm{kg}^{-1}\right)$ & $20.77 \mathrm{c}$ & $23.23 b$ & $24.71 \mathrm{a}$ & 10.3 \\
\hline $\operatorname{Mg}\left(\mathrm{g} \mathrm{kg}^{-1}\right)$ & $3.73 a$ & $4.03 a$ & $3.73 \mathrm{a}$ & 16.8 \\
\hline $\mathrm{B}\left(\mathrm{mg} \mathrm{kg}^{-1}\right)$ & $64.02 \mathrm{~b}$ & $78.63 \mathrm{a}$ & $84.85 \mathrm{a}$ & 16.5 \\
\hline $\mathrm{Cu}\left(\mathrm{mg} \mathrm{kg}^{-1}\right)$ & $33.74 \mathrm{a}$ & $43.58 \mathrm{a}$ & $19.50 \mathrm{~b}$ & 64.8 \\
\hline $\mathrm{Fe}\left(\mathrm{mg} \mathrm{kg}^{-1}\right)$ & $70.85 \mathrm{~b}$ & $77.19 \mathrm{ab}$ & $80.98 \mathrm{a}$ & 18.9 \\
\hline $\operatorname{Mn}\left(m g k^{-1}\right)$ & $19.45 b$ & $26.31 \mathrm{a}$ & $26.34 \mathrm{a}$ & 43.2 \\
\hline $\mathrm{Zn}\left(\mathrm{mg} \mathrm{kg}^{-1}\right)$ & $29.46 b$ & $46.51 \mathrm{a}$ & $37.70 \mathrm{ab}$ & 52.5 \\
\hline
\end{tabular}

(1)Means followed by equal letters, in the columns, do not differ by Tukey's test, at $5 \%$ probability. 
be transferred from the leaf to the fruits. In the case of $\mathrm{Ca}$, due to its restricted mobility in the phloem, accumulation of the nutrient occurs in the leaf tissue throughout plant development.

Since the value of the standard deviation (SD) defines the amplitude of the normal nutrient range, it is expected that the greater the dispersion of nutritional contents in the set of plants of the reference population, the lower the sensitivity of the method to detect nutritional imbalances (Table 4). The amplitude of the CI corresponds to an estimated range, in which the probability that the leaf concentrations of the reference population are included in this range is $99 \%$ $(\mathrm{p} \leq 0.01)$ (Coutinho \& Cunha, 2005). Therefore, the normal nutrient range estimated from the CI usually provides a small amplitude, and is very rigorous in the nutritional diagnosis, as already pointed out for coffee trees (Farnezi et al., 2010) and orange trees (Dias et al., 2013).

In contrast, optimum nutrient contents corresponding to $\pm \mathrm{SD}$ and $\pm 2 / 3 \mathrm{SD}$ of the nutritional indices of the nutritionally balanced population, using DRIS and CND, have already been estimated for mango trees (Politi et al., 2013), cotton plants (Serra et al., 2010; Kurihara et al., 2013), coffee trees (Partelli et al., 2007), and guava plants (Souza et al., 2013), with higher amplitudes than those estimated by CI, but lower amplitudes than the sufficiency ranges (SR) proposed in traditional calibration tests (Quaggio et al., 2005).

In the nutritional diagnosis, the use of smallamplitude SR increases the capacity of the method to identify plants in situations of nutritional imbalance, compared to the use of large-amplitude SR (Partelli et al., 2007). On the other hand, possible minor nutritional variations in the leaf tissue, due to nonnutritional factors, may be interpreted inappropriately (e.g., as nutritional deficiency or excess) when very narrow ranges are used (Jarrel \& Beverly, 1981).

Regardless of the criteria used to establish the normal nutrient ranges in this study, the ranges obtained for $\mathrm{N}$, $\mathrm{P}, \mathrm{B}, \mathrm{Cu}$, and $\mathrm{Zn}$ exceeded the threshold established by Camacho et al. (2012) for 6-month-old fruits in São Paulo orange orchards; while those of $\mathrm{Ca}$ and $\mathrm{Mn}$ were below the threshold, and that of Fe was contained in the range proposed by the authors. However, the critical level established in 'Pêra' orange orchards in the same region of Central Amazônia, with low technological
Table 4. Normal nutrient ranges in 'Pêra' orange (Citrus sinensis) leaves, in three fruiting stages, calculated by the compositional nutrient diagnosis method based on different criteria.

\begin{tabular}{|c|c|c|c|}
\hline Criterion $^{(1)}$ & $\begin{array}{l}\text { 3-month-old } \\
\text { fruits }\end{array}$ & $\begin{array}{c}\text { 6-month-olc } \\
\text { fruits }\end{array}$ & $\begin{array}{c}\text { Main } \\
\text { harvest }\end{array}$ \\
\hline & \multicolumn{3}{|c|}{ Nitrogen $\left(\mathrm{g} \mathrm{kg}^{-1}\right)$} \\
\hline Standard deviation & $28-35$ & $26-31$ & $25-30$ \\
\hline $2 / 3$ of the standard deviation & $29-34$ & $27-30$ & $26-29$ \\
\hline \multirow[t]{2}{*}{ Confidence interval } & $30-33$ & $28-29$ & $27-29$ \\
\hline & \multicolumn{3}{|c|}{ Phosphorus ( $\mathrm{g} \mathrm{kg}^{-1}$ ) } \\
\hline Standard deviation & $1.2-1.5$ & $1.3-1.5$ & $1.4-1.5$ \\
\hline $2 / 3$ of the standard deviation & $1.3-1.4$ & $1.3-1.4$ & $1.4-1.5$ \\
\hline \multirow[t]{2}{*}{ Confidence interval } & $1.3-1.4$ & $1.3-1.4$ & $1.4-1.5$ \\
\hline & \multicolumn{3}{|c|}{ Potassium $\left(\mathrm{g} \mathrm{kg}^{-1}\right)$} \\
\hline Standard deviation & $10-15$ & $7-10$ & $9-12$ \\
\hline $2 / 3$ of the standard deviation & $11-14$ & $8-9$ & $9-11$ \\
\hline \multirow[t]{2}{*}{ Confidence interval } & $12-13$ & $8-9$ & $10-11$ \\
\hline & \multicolumn{3}{|c|}{ Calcium $\left(\mathrm{g} \mathrm{kg}^{-1}\right)$} \\
\hline Standard deviation & $18-24$ & $22-25$ & $23-26$ \\
\hline $2 / 3$ of the standard deviation & $19-23$ & $22-24$ & $24-25$ \\
\hline \multirow[t]{2}{*}{ Confidence interval } & $19-22$ & $22-24$ & $24-25$ \\
\hline & \multicolumn{3}{|c|}{ Magnesium $\left(\mathrm{g} \mathrm{kg}^{-1}\right)$} \\
\hline Standard deviation & $2.8-4.7$ & $1.1-7.0$ & $3.1-4.4$ \\
\hline $2 / 3$ of the standard deviation & $3.1-4.4$ & $2.1-6.0$ & $3.3-4.2$ \\
\hline \multirow[t]{2}{*}{ Confidence interval } & $3.4-4.1$ & $3.0-5.0$ & $3.5-3.9$ \\
\hline & \multicolumn{3}{|c|}{ Boron $\left(\mathrm{mg} \mathrm{kg}^{-1}\right)$} \\
\hline Standard deviation & $57-71$ & $67-92$ & $68-97$ \\
\hline $2 / 3$ of the standard deviation & $59-69$ & $71-88$ & $73-93$ \\
\hline \multirow[t]{2}{*}{ Confidence interval } & $61-67$ & $74-85$ & $77-89$ \\
\hline & \multicolumn{3}{|c|}{ Copper $\left(\mathrm{mg} \mathrm{kg}^{-1}\right)$} \\
\hline Standard deviation & $15-53$ & $16-71$ & $7-32$ \\
\hline $2 / 3$ of the standard deviation & $21-47$ & $25-62$ & $11-28$ \\
\hline \multirow[t]{2}{*}{ Confidence interval } & $26-42$ & $31-56$ & $14-25$ \\
\hline & \multicolumn{3}{|c|}{$\operatorname{Iron}\left(\mathrm{mg} \mathrm{kg}^{-1}\right)$} \\
\hline Standard deviation & $56-86$ & $68-86$ & $64-98$ \\
\hline $2 / 3$ of the standard deviation & $61-81$ & $71-83$ & $70-92$ \\
\hline \multirow[t]{2}{*}{ Confidence interval } & $65-77$ & $73-81$ & $74-88$ \\
\hline & \multicolumn{3}{|c|}{ Manganese $\left(\mathrm{mg} \mathrm{kg}^{-1}\right)$} \\
\hline Standard deviation & $10-29$ & $19-33$ & $13-39$ \\
\hline $2 / 3$ of the standard deviation & $13-26$ & $22-31$ & $18-35$ \\
\hline \multirow[t]{2}{*}{ Confidence interval } & $15-23$ & $23-30$ & $20-32$ \\
\hline & \multicolumn{3}{|c|}{$\left.\operatorname{Zinc}(\mathrm{mg} \mathrm{kg})^{-1}\right)$} \\
\hline Standard deviation & $14-45$ & $27-66$ & $14-62$ \\
\hline $2 / 3$ of the standard deviation & $19-40$ & $34-59$ & $22-54$ \\
\hline Confidence interval & $23-36$ & $37-56$ & $26-49$ \\
\hline
\end{tabular}

${ }^{(1)}$ Criteria underlying the normal range: $\mathrm{CI}$, confidence interval of nutritional contents in leaves of plants of the reference population; SD, range between \pm the standard deviation of the nutritional contents in the reference population; and $\pm^{2} / 3 \mathrm{SD}$, range between $\pm^{2} / 3$ of the standard deviation of the nutritional contents in the reference population. 
level and fruits of the same age (Dias et al., 2013), was higher than the normal ranges established here for $\mathrm{P}$, $\mathrm{Ca}$, and $\mathrm{Fe}$; below those for $\mathrm{K}, \mathrm{B}, \mathrm{Cu}$, and $\mathrm{Zn}$; and within the ranges for $\mathrm{N}, \mathrm{Mg}$ and $\mathrm{Mn}$, in most cases.

The distribution frequencies of the nutritional classes of deficiency, balance and excess, observed in low-yield plots, were close to the expected frequencies for most of the nutrients, and random in the case of $\mathrm{N}$ using the normal range based on the criteria CI and $\pm \mathrm{SD}$, and in the case of $\mathrm{K}$ using the $\pm \mathrm{SD}$ criterion (Table 5).

All normal ranges indicated $\mathrm{Zn}, \mathrm{Ca}$ and $\mathrm{Fe}$ as the elements that most frequently limit yields of 'Pêra' orange in the Amazonas region, and in more than 65\% of the monitored plots, at least one of these nutrients was deficient. Nonetheless, $\mathrm{Mg}$ most often fitted within the established normal nutrient ranges, in more than $92 \%$ of the diagnosed plots (Table 5 ).

The degree of agreement in the diagnoses based on normal ranges and the criteria $\mathrm{CI}$ and $\pm 2 / 3 \mathrm{SD}$ in the different fruiting stages was higher than $79 \%$ for most nutrients and reached $100 \%$ for $\mathrm{P}$ and $\mathrm{Ca}$ (Table 6). However, the degree of agreement at different sampling times, regardless of the criterion adopted to establish the normal range, was less than $65 \%$ for most nutrients.

The variation in leaf nutrient contents according to the fruiting stage may be associated with several factors

Table 5. Frequency at which nutritional deficiency, balance and nutritional excess were detected in 30 plots with low yields, according to the Compositional nutrient diagnosis method using different criteria to establish the normal range, in 'Pêra' orange (Citrus sinensis) trees evaluated in three-month-old fruits.

\begin{tabular}{lcccc}
\hline Criterion $^{(1)}$ & Deficiency & Equilibrum & Excess & Chi-square \\
\hline & \multicolumn{5}{c}{ Nitrogen } \\
Standard deviation & 4 & 24 & 2 & $* *$ \\
$2 / 3$ of the SD & 7 & 17 & 6 & $\mathrm{~ns}$ \\
Confidence interval & 10 & 4 & 16 & $* *$ \\
Expected frequency & 7.0 & 15.0 & 8.0 & - \\
\hline & & Phosphorus & \\
Standard deviation & 12 & 16 & 2 & $\mathrm{~ns}$ \\
$2 / 3$ of the SD & 12 & 8 & 10 & $\mathrm{~ns}$ \\
Confidence interval & 12 & 8 & 10 & $\mathrm{~ns}$ \\
Expected frequency & 12.0 & 10.7 & 7.3 & - \\
\hline
\end{tabular}

Continuation...
Continuation...

\begin{tabular}{|c|c|c|c|c|}
\hline \multirow[b]{2}{*}{ Standard deviation } & \multicolumn{4}{|c|}{ Potassium } \\
\hline & 4 & 21 & 5 & $* *$ \\
\hline $2 / 3$ of the SD & 10 & 8 & 12 & ns \\
\hline Confidence interval & 10 & 8 & 12 & ns \\
\hline \multirow[t]{2}{*}{ Expected frequency } & 8.0 & 12.3 & 9.7 & - \\
\hline & \multicolumn{4}{|c|}{ Calcium } \\
\hline Standard deviation & 22 & 7 & 1 & ns \\
\hline $2 / 3$ of the SD & 23 & 4 & 3 & ns \\
\hline Confidence interval & 23 & 4 & 3 & ns \\
\hline \multirow[t]{2}{*}{ Expected frequency } & 22.7 & 5.0 & 2.3 & - \\
\hline & \multicolumn{4}{|c|}{ Magnesium } \\
\hline Standard deviation & 1 & 28 & 1 & ns \\
\hline $2 / 3$ of the SD & 1 & 28 & 1 & ns \\
\hline Confidence interval & 8 & 21 & 1 & ns \\
\hline \multirow[t]{2}{*}{ Expected frequency } & 3.3 & 25.3 & 1.0 & - \\
\hline & \multicolumn{4}{|c|}{ Boron } \\
\hline Standard deviation & 20 & 4 & 6 & ns \\
\hline $2 / 3$ of the SD & 21 & 1 & 8 & ns \\
\hline Confidence interval & 21 & 1 & 8 & ns \\
\hline \multirow[t]{2}{*}{ Expected frequency } & 20.7 & 2.0 & 7.3 & - \\
\hline & \multicolumn{4}{|c|}{ Copper } \\
\hline Standard deviation & 18 & 9 & 3 & ns \\
\hline $2 / 3$ of the SD & 22 & 5 & 3 & ns \\
\hline Confidence interval & 24 & 3 & 3 & ns \\
\hline \multirow[t]{2}{*}{ Expected frequency } & 21.3 & 5.7 & 3.0 & - \\
\hline & \multicolumn{4}{|c|}{ Iron } \\
\hline Standard deviation & 20 & 9 & 1 & ns \\
\hline $2 / 3$ of the SD & 22 & 7 & 1 & ns \\
\hline Confidence interval & 23 & 6 & 1 & ns \\
\hline \multirow[t]{2}{*}{ Expected frequency } & 21.7 & 7.3 & 1.0 & - \\
\hline & \multicolumn{4}{|c|}{ Manganese } \\
\hline Standard deviation & 21 & 7 & 2 & ns \\
\hline $2 / 3$ of the SD & 21 & 5 & 4 & ns \\
\hline Confidence interval & 22 & 3 & 5 & $\mathrm{~ns}$ \\
\hline \multirow[t]{2}{*}{ Expected frequency } & 21.3 & 5.0 & 3.7 & - \\
\hline & \multicolumn{4}{|c|}{ Zinc } \\
\hline Standard deviation & 21 & 7 & 2 & ns \\
\hline $2 / 3$ of the SD & 24 & 1 & 5 & ns \\
\hline Confidence interval & 24 & 1 & 5 & ns \\
\hline Expected frequency & 23.0 & 3.0 & 4.0 & - \\
\hline
\end{tabular}


Table 6. Degree of agreement (\%) between diagnoses based on normal ranges obtained from different criteria, of 'Pêra' orange (Citrus sinensis) trees sampled at different fruiting stages.

\begin{tabular}{|c|c|c|c|c|c|c|c|c|c|c|}
\hline \multirow[t]{2}{*}{ Diagnosis $^{(1)}$} & $\mathrm{N}$ & $\mathrm{P}$ & $\mathrm{K}$ & $\mathrm{Ca}$ & $\mathrm{Mg}$ & $\mathrm{B}$ & $\mathrm{Cu}$ & $\mathrm{Fe}$ & $\mathrm{Mn}$ & $\mathrm{Zn}$ \\
\hline & \multicolumn{10}{|c|}{ Three-month-old fruits (Frt3) } \\
\hline SD vs. ${ }^{2} / 3 \mathrm{SD}$ & 83 & 77 & 73 & 83 & 77 & 90 & 50 & 83 & 87 & 93 \\
\hline SD vs. CI & 63 & 77 & 47 & 83 & 47 & 77 & 57 & 63 & 77 & 90 \\
\hline \multirow[t]{2}{*}{$2 / 3 \mathrm{SD}$ vs. CI } & 80 & 100 & 73 & 100 & 70 & 87 & 80 & 80 & 90 & 97 \\
\hline & \multicolumn{10}{|c|}{ Six-month-old fruits (Frt6) } \\
\hline $\mathrm{SD}$ vs. $2 / 3 \mathrm{SD}$ & 77 & 73 & 57 & 90 & 100 & 90 & 87 & 93 & 93 & 80 \\
\hline SD vs. CI & 33 & 73 & 57 & 90 & 70 & 90 & 80 & 90 & 87 & 80 \\
\hline \multirow[t]{2}{*}{$2 / 3 \mathrm{SD}$ vs. CI } & 57 & 100 & 100 & 100 & 70 & 100 & 93 & 97 & 93 & 100 \\
\hline & \multicolumn{10}{|c|}{ Main harvest (MH) } \\
\hline SD vs. $2 / 3 \mathrm{SD}$ & 87 & 100 & 83 & 93 & 73 & 87 & 67 & 67 & 97 & 93 \\
\hline SD vs. CI & 80 & 100 & 60 & 93 & 57 & 63 & 57 & 53 & 97 & 93 \\
\hline \multirow[t]{2}{*}{$2 / 3 \mathrm{SD}$ vs. CI } & 93 & 100 & 77 & 100 & 83 & 77 & 90 & 87 & 100 & 100 \\
\hline & \multicolumn{10}{|c|}{ Standard deviation (SD) } \\
\hline Frt3 vs. Frt6 & 37 & 43 & 60 & 67 & 80 & 47 & 60 & 33 & 77 & 77 \\
\hline Frt3 vs. MH & 57 & 47 & 53 & 73 & 63 & 60 & 60 & 57 & 83 & 90 \\
\hline \multirow[t]{2}{*}{ Frt6 vs. MH } & 57 & 57 & 63 & 80 & 57 & 60 & 57 & 27 & 83 & 87 \\
\hline & \multicolumn{10}{|c|}{$2 / 3$ of the standard deviation $(2 / 3 \mathrm{SD})$} \\
\hline Frt3 vs. Frt6 & 37 & 43 & 40 & 67 & 57 & 50 & 50 & 40 & 80 & 73 \\
\hline Frt3 vs. MH & 47 & 60 & 37 & 77 & 47 & 53 & 53 & 63 & 90 & 90 \\
\hline \multirow[t]{2}{*}{ Frt6 vs. MH } & 43 & 57 & 47 & 77 & 30 & 63 & 73 & 40 & 87 & 77 \\
\hline & \multicolumn{10}{|c|}{ Confidence interval $(\mathrm{CI})$} \\
\hline Frt3 vs. Frt6 & 27 & 43 & 47 & 67 & 53 & 53 & 57 & 57 & 73 & 77 \\
\hline Frt3 vs. MH & 50 & 60 & 30 & 77 & 60 & 67 & 57 & 60 & 80 & 93 \\
\hline Frt6 vs. MH & 20 & 57 & 43 & 77 & 43 & 80 & 80 & 53 & 90 & 77 \\
\hline
\end{tabular}

related to plant physiology, e.g., nutritional demands resulting from fruiting and the development of vegetative and reproductive branches. In addition, this variation may also be related to meteorological variables, which interfere with plant development (Fageria et al., 2009).

\section{Conclusions}

1. The nutritional status of 'Pêra' orange (Citrus sinensis) trees cultivated in Amazonas varies according to the season of leaf sampling, regardless of the normal nutrient range underlying the diagnosis.

2. Normal nutrient ranges obtained from the criteria of the confidence interval and $\pm^{2 / 3}$ of the standard deviation of the nutritional levels observed in the reference population often provided similar nutritional diagnoses.

3. The $\mathrm{Zn}, \mathrm{Ca}$, and $\mathrm{Fe}$ are the elements that most often limit the yield in the production of 'Pêra' orange in the state of Amazonas, Brazil.

\section{References}

BEAUFILS, E.R. Diagnosis and recommendation integrated system (DRIS): a general scheme for experimentation and calibration based on principles develop from research in plant nutrition. Pietermaritzburg: University of Natal, 1973. 132p. 
BOARETTO, R.M.; MATTOS JUNIOR, D.; TRIVELIN, P.C.O.; MURAOKA, T.; BOARETTO, A.E. Acúmulo de nutrientes e destino do nitrogênio $\left({ }^{15} \mathrm{~N}\right)$ aplicado em pomar jovem de laranjeira. Revista Brasileira de Fruticultura, v.29, p.600-605, 2007. DOI: 10.1590/S0100-29452007000300035.

CAMACHO, M.A.; SILVEIRA, M.V. da; CAMARGO, R.A.; NATALE, W. Faixas normais de nutrientes pelos métodos ChM, DRIS e CND e nível crítico pelo método de distribuição normal reduzida para laranjeira-pera. Revista Brasileira de Ciência do Solo, v.36, p.193-200, 2012. DOI: 10.1590/S010006832012000100020 .

CARMO, C.A.F. de S. do; ARAÚJO, W.S. de; BERNARDI, A.C. de C.; SALDANHA, M.F.C. Métodos de análise de tecidos vegetais utilizados pela Embrapa Solos. Rio de Janeiro: Embrapa Solos, 2000. 41p.

COUTINHO, E.S.F.; CUNHA, G.M. da. Conceitos básicos de epidemiologia e estatística para leitura de ensaios clínicos controlados. Revista Brasileira de Psiquiatria, v.27, p.145-151, 2005. DOI: 10.1590/S1516-44462005000200015.

DIAS, J.R.M.; TUCCI, C.A.F.; WADT, P.G.S.; SILVA, A.M. da; SANTOS, J.Z.L. Níveis críticos e faixas de suficiência nutricional em laranjeira-pêra na Amazônia Central obtidas pelo método DRIS. Acta Amazonica, v.43, p.239-249, 2013. DOI: 10.1590/ S0044-59672013000300001.

DONAGEMA, G.K.; CAMPOS, D.V.B. de; CALDERANO, S.B.; TEIXEIRA, W.G.; VIANA, J.H.M. (Org.). Manual de métodos de análise de solo. 2.ed. rev. Rio de Janeiro: Embrapa Solos, 2011. 230p. (Embrapa Solos. Documentos, 132).

FAGERIA, N.K.; BARBOSA FILHO, M.P.; MOREIRA, A.; GUIMARÃES, C.M. Foliar fertilization of crop plants. Journal of Plant Nutrition, v.32, p.1044-1064, 2009. DOI: 10.1080/01904160902872826.

FARNEZI, M.M. de M.; SILVA, E. de B.; GUIMARÃOES, P.T.G. Diagnose nutricional de cafeeiros da região do alto Jequitinhonha (MG): normas DRIS e faixas críticas de nutrientes. Revista Brasileira de Ciência do Solo, v.33, p.969-978, 2009. DOI: 10.1590/S0100-06832009000400021.

FERNANDES, A.R.; REIS, I.N.R.S.; NORONHA, N.C. Estado nutricional de pomares de laranjeira submetidos a diferentes manejos do solo. Revista de Ciências Agrárias, v.53, p.52-58, 2010. DOI: $10.4322 /$ rca.2011.007.

HALLMARK, W.B.; WALWORTH, J.L.; SUMNER, M.E.; DE MOOY, C.J.; PESEK, J.; SHAO, K.P. Separating limiting from non-limiting nutrients. Journal of Plant Nutrition, v.10, p.13811390, 1987.

IBGE. Instituto Brasileiro de Geografia e Estatística. Mapas: Amazonas. 2010. Available at: <ftp:/geoftp.ibge.gov.br/ informacoes_ambientais/pedologia/mapas/unidades_da_ federacao/am_pedologia.pdf $>$. Accessed on: July 12016.

IBGE. Instituto Brasileiro de Geografia e Estatística. Produção agrícola estadual: lavoura permanente 2012. Available at: $<$ http:// www.ibge.gov.br/estadosat>. Accessed on: Jan. 102014.
JARREL, W.M.; BEVERLY, R.B. The dilution effect in plant nutrition studies. Advances in Agronomy, v.34, p.197-224, 1981. DOI: $10.1016 / \mathrm{S} 0065-2113(08) 60887-1$.

KURIHARA, C.H.; MAEDA, S.; ALVAREZ V., V.H. Interpretação de resultados de análise foliar. Dourados: Embrapa Agropecuária Oeste; Colombo: Embrapa Floresta, 2005. 42 p. (Embrapa Agropecuária Oeste. Documentos, 74).

KURIHARA, C.H.; VENEGAS, V.H.A.; NEVES, J.C.L.; NOVAIS, R.F. de; STAUT, L.A. Faixas de suficiência para teores foliares de nutrientes em algodão e em soja, definidas em função de índices DRIS. Revista Ceres, v.60, p.412-419, 2013. DOI: 10.1590/S0034-737X2013000300015.

MATTOS JUNIOR, D.; QUAGGIO, J.A.; CANTARELLA, H.; ALVA, A.K. Nutrient content of biomass components of Hamlin sweet orange trees. Scientia Agricola, v.60, p.155-160, 2003. DOI: $10.1590 / \mathrm{S} 0103-90162003000100023$.

MOURÃO FILHO, F. de A.A. DRIS and sufficient range approaches in nutritional diagnosis of "Valencia" sweet orange on three rootstocks. Journal of Plant Nutrition, v.28, p.691-705, 2005. DOI: 10.1081/PLN-200052645.

PARENT, L.-É. Diagnosis of the nutrient compositional space of fruit crops. Revista Brasileira de Fruticultura, v.33, p.321-334, 2011. DOI: 10.1590/S0100-29452011000100041.

PARENT, L.E.; DAFIR, M. A theoretical concept of compositional nutrient diagnosis. Journal of American Society of Horticultural Science, v.117, p.239-242, 1992.

PARTELLI, F.L.; VIERA, H.D.; CARVALHO, V.B. de; MOURÃO FILHO, F. de A.A. Diagnosis and recommendation integrated system norms, sufficiency range, and nutritional evaluation of Arabian coffee in two sampling periods. Journal of Plant Nutrition, v.30, p.1651-1667, 2007. DOI: 10.1080/01904160701615525.

PEREZ, O.C.; SANTOS, V.H.A. dos. Exportação de suco de laranja brasileiro. Revista de Administração da FATEA, v.9, p.101-109, 2014.

POLITI, L.S.; FLORES, R.A.; SILVA, J.A.S. da; WADT, P.G.S.; PINTO, P.A. da C.; PRADO, R. de M. Estado nutricional de mangueiras determinado pelos métodos DRIS e CND. Revista Brasileira de Engenharia Agrícola e Ambiental, v.17, p.11-18, 2013. DOI: $10.1590 /$ S1415-43662013000100002.

QUAGGIO, J.A.; MATTOS JUNIOR, D.; CANTARELLA, H. Manejo da fertilidade do solo na citricultura. In: MATTOS JUNIOR, D. de; DE NEGRI, J.D.; PIO, R.M.; POMPEU JUNIOR, J. (Ed.). Citrus. Campinas: Instituto Agronômico de Campinas, 2005. p.483-507.

SANTANA, J. das G.; LEANDRO, W.M.; NAVES, R.V.; CUNHA, P.P. da; ROCHA, A.C. Estado nutricional da laranja Pêra na região central do estado de Goiás avaliada pelas análises foliar e do solo. Bioscience Journal, v.23, p.40-49, 2007.

SANTOS, A.L. dos; MONNERAT, P.H.; CARVALHO, A.J.C. de. Estabelecimento de normas DRIS para o diagnóstico do coqueiroanão verde na região Norte Fluminense. Revista Brasileira de Fruticultura, v.26, p.330-334, 2004. DOI: 10.1590/S010029452004000200035. 
SERRA, A.P.; MARCHETTI, M.E.; VITORINO, A.C.T.; NOVELINO, J.O.; CAMACHO, M.A. Determinação de faixas normais de nutrientes no algodoeiro pelos métodos ChM, CND e DRIS. Revista Brasileira de Ciência do Solo, v.34, p.97-104, 2010. DOI: 10.1590/S0100-06832010000100010.

SILVA, F. de A.S. e; AZEVEDO, C.A.V. de. Versão do programa computacional Assistat para o sistema operacional Windows. Revista Brasileira de Produtos Agroindustriais, v.4, p.71-78, 2002. DOI: 10.15871/1517-8595/rbpa.v4n1p71-78.

SOUZA, H.A. de; ROZANE, D.E.; AMORIM, D.A. de; NATALE, W. Normas preliminares DRIS e faixas de suficiência para goiabeira 'Paluma'. Revista Brasileira de Fruticultura, v.35, p.282-291, 2013. DOI: 10.1590/S0100-29452013000100033.

SRIVASTAVA, A.K.; SINGH, S. DRIS norms and their field validation in Nagpur mandarin. Journal of Plant Nutrition, v.31, p.1091-1107, 2008. DOI: 10.1080/01904160802115359.

TEIXEIRA, L.A.J.; ZAMBROSI, F.C.B.; BETTIOL NETO, J.E. Avaliação do estado nutricional de bananeiras do subgrupo Cavendish no estado de São Paulo: normas DRIS e níveis críticos de nutrientes. Revista Brasileira de Fruticultura, v.29, p.613-620, 2007. DOI: 10.1590/S0100-29452007000300037.

Received on December 20, 2015 and accepted on November 4, 2016 